ARQGA / 1105

\title{
EFFECTS ON GROWTH AFTER HYPERTENSION PORTAL INDUCED IN YOUNG RATS
}

\author{
Luiz Eduardo Correia MIRANDA ${ }^{1}$, Reginaldo CENEVIVA ${ }^{1}$ and Hélio VANNUCCHI ${ }^{2}$
}

\begin{abstract}
Background-Physical growth retardation in children with hypertension por tal was observed regardless of schistosomiasis. It has been suggested that the shunt of portal blood through portosystemic collateral vessels would result in metabolic consequences that would lead to the physical growth def icit observed. Aim - Study the effects of hypertension portal in the growth of young rats. Methods - The g rowth of $20 \mathrm{y}$ oung rats, divided in the groups hypertension portal, $\mathrm{n}=10,1033.7 \mathrm{~g}$ and sham operation $\mathrm{n}=10,102.6 \pm 3.4 \mathrm{~g}$ was evaluated throughout 5 weeks and the following parameters were under observation: quality of diet offered, diet ingestion, weight increase and urinary creatinine within 24 hours. At the end of the experiment, blood was taken for biochemical tests, prothrombin time and hematocrit and hypertension portal was measured. Results/Conclusions - Rats with hypertension portal induced at early stages of their lives present growth delay in the first week after surgery recovering their growth rhythm in the next weeks, catching up with the sham animals. Differences related to urinary creatinine excretion, biochemical tests and hematocrit were not observed. Such results are evidence against the hypothesis that the hypertension portal induced in early stages of rats lives would cause delay in their growth.
\end{abstract}

HEADINGS - Hypertension, portal. Growth disorders. Rats.

\section{INTRODUCTION}

Growth retardation has been related to the hepatosplenic forms of schistosomiasis, a common cause of portal hypertension (HP) in several parts of world ${ }^{(6,10,11,12)}$. The causes of the supposed growth deficit are ignored. It has been suggested that the final minor a vailability of nutrients, in part due to smaller absorption, blood and nutrients loss in the stools and anorexia, can be responsible factors for the clinical findings in the infested children ${ }^{(17)}$. However, SARIN et al. ${ }^{(15)}$ and SARIN and AGARWAL ${ }^{(16)}$ observed growth retardation in children with vein portal extra-hepatic obstruction regardless schistosomiasis, suggesting the shunt of hepatic blood supply by the obstruction portal as the probable causes of the growth deficit. It was suggest that HP could limit the secretion of a hepatic factor with direct influence in the growth. This suggestion was not experimentally tested. There are no experiments aiming at inducing HP in early stages of animals lives to study the growth rhythm in its most intense period, neither it was established as a parameter of control, the diet ingestion or the quality of the diet offered to the animals, nor were established parameters related to their nutritional status. The purpose of the current study was to determine whether the growth retardation observed in children with hypertension portal can be experimentally reproduced to test the hypothesis that HP may cause growth retardation in rats.

\section{MATERIAL AND METHODS}

This study was performed in accordance with guidelines for animal experimentation of São Paulo University.

Twenty males Wistar rats weighing near $100 \mathrm{~g}$, were divided into two groups: group HP $(103 \pm 3.7 \mathrm{~g}, \mathrm{n}=10)$, rats with portal hypertension, and group $\mathrm{S}(102.6 \pm 3.4 \mathrm{~g}$, $\mathrm{n}=10)$, rats subjected to the sham operation. HP was induced like previously described ${ }^{(13)}$. Briefly, after a period of 48 hours of adaptation, the animals were anesthetized with ether

Department of Surgery and Anatomy and ${ }^{2}$ Department of Clinical Medicine, Ribeirão Preto Medical School, São Paulo, University, Ribeirão Preto, SP, Brazil.

Address for correspondence: Dr. Luiz Eduardo C. Miranda - Rua Dhália, 74 - Boa Viagem - 51020-290 - Recife, PE, Brazil.

E-mail: lecmiranda@terra.com.br 
ethilic and subjected to median laparotomy. HP was achieved by the positioning of a clip with internal size of $0,3 \mathrm{~mm}$ in the portal vein after the drainage site of its last tributary. The animals in group $\mathrm{S}$ were subjected to the same surgical procedure without placing the silver clip. The animals were housed in metabolic cages for 35 days, in acclimatized rooms with equal periods of absence and presence of light, and fed with standardized diet, composed for proteins to casein base, saline and vitaminic mixtures according to parameters of the AOAC - Association of Official Analytical Chemists $^{(3)}$. The proteic content of the diet's nitrogen source was determined by Kjeldahl's method ${ }^{(5)}$, by means of the evaluation of five diet samples, to guarantee its quality and homogeneity. Experimental outline: the rats were weighed at the beginning of the adaptation period (P0), just before de surgical act (P1), and from the 9 th postoperative day, once a week (days 9, 16, 23, 30 and 35, identified like P9, P16, etc.), always between 8 and 9 a.m., and strictly in the same day of postoperative for different groups. The variation of weight was considered weekly, which corresponds to the difference between two consecutive measures spaced by 1 week. A measure was thus obtained just before de surgical act, called V0, which corresponds to the variation of weight between the $1^{\text {st }}$ adaptation day and the surgery day, and five postoperative measures, V1's nominees V5. For the animals' weighing an electronic scales graduated in $1 \mathrm{~g}$ were used. The alimentary ingestion control was followed at least twice a week, between 8 and 9 a.m., calculating the difference between the offered diet weight and the weight of the remaining of the alimentary compartment. At the end of the $1^{\text {st }}, 3^{\text {rd }}$ and $5^{\text {th }}$ experiment weeks urine was collected during of 24 hours, by means of a graduated glass installed externally to the cage, for dosage of creatinine urinary excretion, with the goal of checking the animals' muscle mass gain. At the end of 5 weeks the animals were again operated on for pressure portal evaluation, which was carried out by means of transesplenic measure ${ }^{(4)}$. Blood was collected for hematocrit, biochemical and prothrombin time tests. The biochemical tests were carried out in the laboratory of Biochemistry of the Hospital of Clinics, Ribeirão Preto Medical School, São Paulo University, Ribeirão Preto, SP, Brazil. The hematocrit was held automatically in device model COUTER T. Prothrombin time values were accomplished electronically in device model ELECTRA $1600 \mathrm{C}$.

\section{Statistical analysis}

The values of each parameter in each group were expressed as arithmetic averages and standard deviation (means \pm SD). It was applied $t$ Student test for animals weight and diet ingestion data analysis. For the other parameters it was applied Mann-Whitney's test. Differences were considered significant at the le vel of $P<0.05$.

\section{RESULTS}

\section{Diet ingestion}

The animals ingested similar amounts of diet during the adaptation period. Diet ingestion was significantly lower in group HP in the $1^{\text {st }}$ week postoperatory $(9.8 \pm 1.8 \mathrm{~g}, \mathrm{n}=10 v s 14.02 \pm 2.9 \mathrm{~g}, \mathrm{n}=10$, $P<0.05)$. For the other experiment weeks there was no difference in the diet ingestion by different groups (Figure 1).

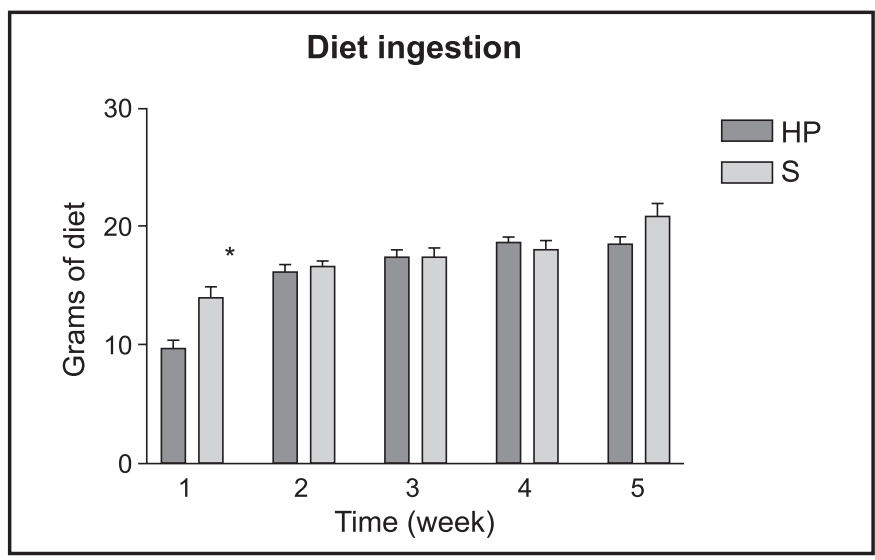

FIGURE 1 -Diet ingestion (g) by week. Each value represents the mean \pm standard deviation of 10 experiments. There is statistically significant difference (*test $t$ Student, $P<0.05)$ in the $1^{\text {st }}$ postoperative week

\section{Weight evolution}

There was no significant difference between groups HP and S during the adaptation period. Weight was significantly higher in group $\mathrm{S}$ for the first measure $(\mathrm{P} 9,124.1 \pm 4.2 \mathrm{~g}, \mathrm{n}=10$ group HP $v$ s $151.9 \pm 16.8, \mathrm{n}=10$, group $\mathrm{S}, P<0.05)$. There was no statistically relevant difference for the other measures (Figure 2).

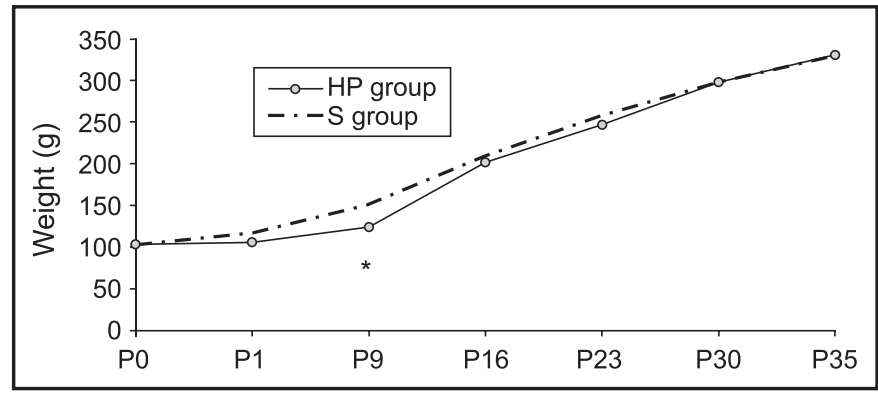

FIGURE 2 -Weight evolution according to time of postoperative evolution. There is statistically significant difference in $\mathrm{P} 9$ that cor responds to the $9^{\text {th }}$ postoperative day (test $t$ Student, $P<0.05)$. P0 corresponds to the weight at the beginning of the adaptation phase and $\mathrm{P} 1$ corresponds to the weight in the surgery day 


\section{Weekly weight gain}

The animals gained weight equally during the adaptation time $(4.8 \pm 2.7 \mathrm{~g}, \mathrm{n}=10$, group HP $v s 5.2 \pm 3.5 \mathrm{~g}, \mathrm{n}=10$ group S). Weekly weight gain was significantly different in V1 and V4 that correspond to the $1^{\text {st }}$ and $4^{\text {th }}$ postoperative weeks $(24 \pm 12.0 \mathrm{~g}, \mathrm{n}=10$, group $\mathrm{HP}$, and of $44.1 \pm 12.4 \mathrm{~g}, \mathrm{n}=10$, group $\mathrm{S}, P<0.05$ and $50.3 \pm 15.12 \mathrm{~g}$, $\mathrm{n}=10$, group HP, and $38.3 \pm 6.8, \mathrm{n}=9$, group $\mathrm{S}, P<0.05$ ) (Figure 3 ).

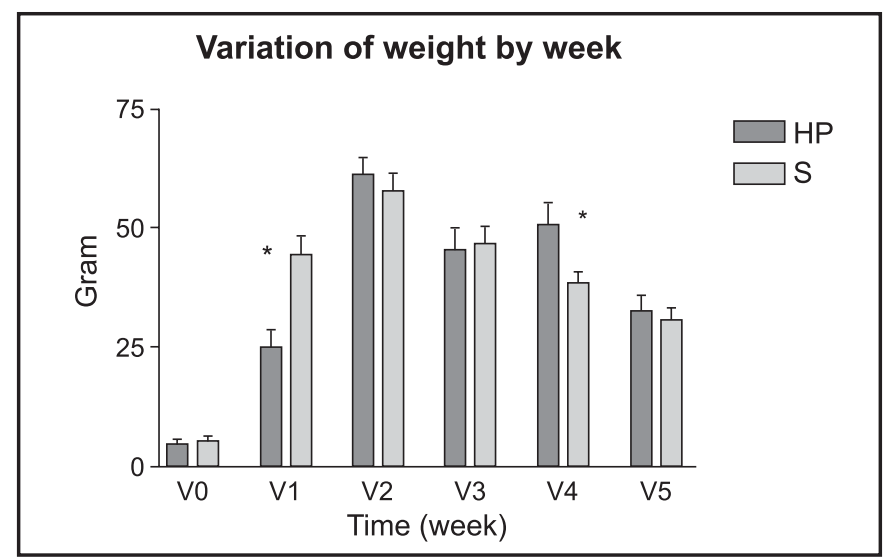

FIGURE 3 - Variation of weight by week. Each value represents the mean \pm standard deviation of 10 experiments. There is statistically significant difference in V1 and in V4 that correspond the $1^{\text {st }}$ and $4^{\text {th }}$ postoperative weeks (test $t$ Student, $P<0.05$ )

\section{Urinary creatinine}

There was no difference in the creatinine urinary excretion measured in 24 hours (Figure 4).

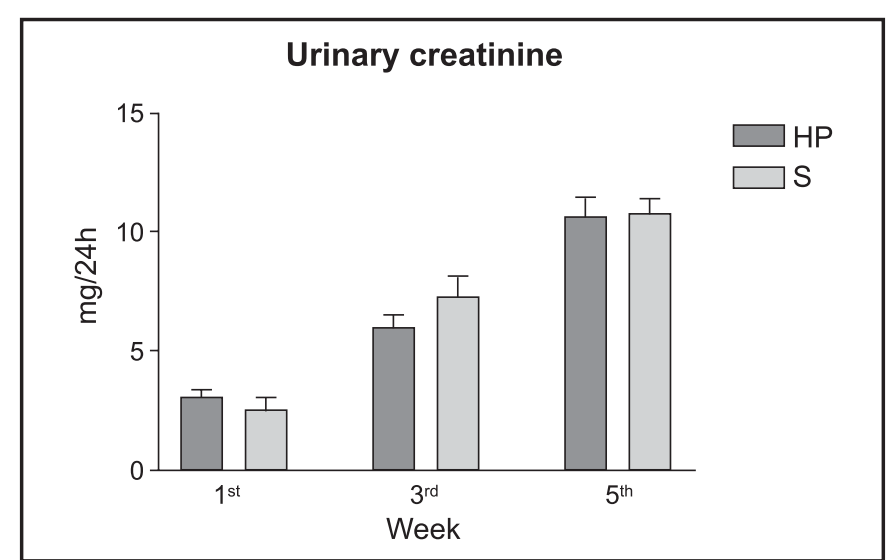

FIGURE 4 - Creatinine urinary excretion according to postoperative week. Each value represents the mean \pm standard deviation of 10 experiments. There is no statistically significant difference between values of creatinine urinary excretion for the groups $\mathrm{HP}$ and $\mathrm{S}$

\section{Hematocrit and blood biochemical analysis}

There were no differences for determination of ALT, AST, albumin, alkaline phosphatase, bilirubins total and conjugated, hematocrit and prothrombin time between groups HP and S.

\section{Portal pressure}

The values of pressure portal were markedly elevated signif icantly in group HP compared with group $\mathrm{S}(20.3 \pm 2.6 \mathrm{~mm} \mathrm{Hg} \mathrm{n}=9$ vs 9.3 $\pm 2.4 \mathrm{~mm} \mathrm{Hg}, \mathrm{n}=7, P<0.05$ )

\section{DISCUSSION}

The relationship between HP and children's growth is not clearly established in the literature. Most authors that studied HP did not have as a main aim evaluating the growth or nutritional status of patients ${ }^{(18)}$. However, SARIN et al. ${ }^{(15)}$ accompanying every 3 or 6 months, 61 young patients with average of $8.4 \pm 5.4$ years age and carriers of extra-hepatic HP, and evaluating anthropometric indices, growth rhythm, diet and nutritional parameters, concluded that most children with vein por tal thrombosis are smaller in stature and present smaller growth speed when compared to the healthy controls. The groups were similar in age, gender, racial and social conditions. There is evidence of abnormal secretion and dynamics of growth hormone $(\mathrm{GH})$, so much in patients with cirrhosis as in patients with schistosomiasis $^{(2)}$. ASSAD et al. ${ }^{(2)}$ suggest that the insulin shunt through the collateral portosystemics vessels leads to the synthesis decrease of the growth insulin-simile factor I (IGF I) by the liver, which results in increase secretion GH. Chronic liver disease is associated with GH resistance, which is characterized by high circulating $\mathrm{GH}$ and low $\operatorname{IGF}^{(1,8)}$. According to ASSAD et al. ${ }^{(2)}$, the secretion alterations of $\mathrm{GH}$ would be consequence of blood deviation by the collateral vessels, and not of the hepatic parenchyma disease. Children carriers of hypertension portal who underwent surgical portosystemic shunting have improved postoperative growth parameters $^{(9)}$ suggesting that systemic shunting, is not the only responsible by the growth delay. There is no experimental research evaluating the growth of animals with extra-hepatic hypertension portal induced in early phase of their lives. Acute portal vein stenosis is a reliable method to induce hypertension portal in rats ${ }^{(14)}$. Clip with internal size of $0,3 \mathrm{~mm}$ induces hypertension portal and evident development of portosystemic vessels in young rats how can be demonstrated by means of por tography ${ }^{(13)}$ (Figure 5) and transesplenic measure of portal pressure. In the present study HP was induced in early stages of animals growth, the quantity of consumed diet was checked in order to exclude the anorexia as a possible cause of bias in the growth evaluation, the diet quality was assured to guarantee 
(A)

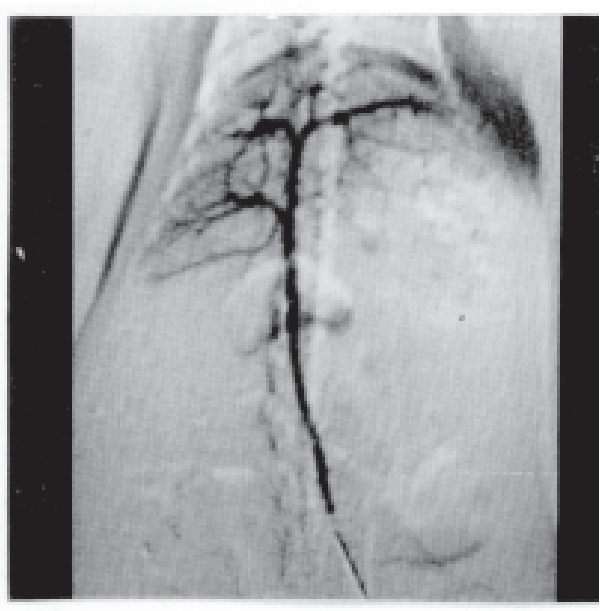

(B)

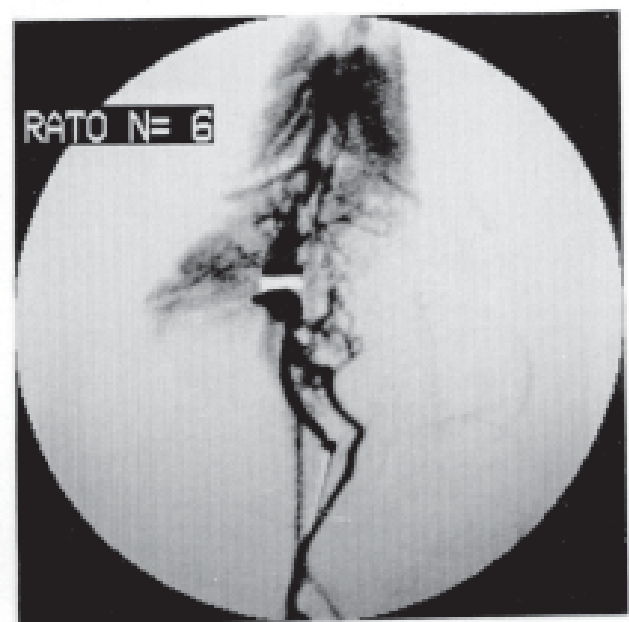

FIGURE 5 -(A) Portography of the group S. The portal vein has no collateral vessels. (B) Portography of the group HP. There is evident blood shunt through the collateral portosystemic vessels (MIRANDA $\left.{ }^{(13)}\right)$

that the different studied groups had received a diet with adequate quality for their perfect growth and the weight and muscle mass gain were considered as growth parameters. It is important to mention at this point that dosage of creatinine urinary excretion in 24 hours is adequate method for the muscle mass corporal evaluation since a diet exempt of creatinine and creatina is offered ${ }^{(7)}$. The referring values evaluation to creatinine excretion in 24 hours, suggest that the fact of the animals grew in conditions to HP was not enough to provoke delay in the muscle mass $\mathrm{g}$ ain, suggesting that HP does not decrease the availability nor the nutrients utilization. The animals did not have ascites, nor any difference in the muscle mass gain. It was considered that the g ain of weigh was a good parameter for the growth evaluation. The analysis of weight gain shows that in the $2^{\text {nd }}$ week the animals acquired $60.7 \pm 12.4 \mathrm{~g}$, group HP and $57.6 \pm 11 \mathrm{~g}$, group S. In that week the animals weighed about 200 to $210 \mathrm{~g}$. The weight gain represented about $30 \%$ of the animals weight in this short period of time. The referring data analysis to the weekly weight gain demonstrates that the $2^{\text {nd }}$ week corresponded to the most intense increase in rats weight, being this growth rhythm decreased in the subsequent weeks. The experiment was developed, therefore, in the animals' fastest growth phase, situation that imposes big metabolic requirements. Time of study can also be considered convenient, if considered that in the 5 studied weeks the animals weight tripled, fact that does not happen in any other following period of these animals lives. The referring data analysis to the weight gain demonstrates that the animals of group HP got less weight than the control animals in the period that corresponds to the 9 early postoperative days, while the inverse happened on the $4^{\text {th }}$ week of the experiment. At the end of 5 weeks there were no differences for the weight variations between animals in both groups. The anorexia presented by the animals in group HP during early postoperative days, reflected by the smaller alimentary ingestion during this period, can be explained by the strong surgical injury made by HP's induction. When the animals recovered from this period, they took diet in larger quantity, they quickly recovered their weight and approached the group $\mathrm{S}$ growth rhythm. The fact that it was offered balanced, homogeneous diet, and with adequate protein composition to the animals growth, ingested in enough quantities, excludes the possibility of any difference in the growth being caused by the offer of bad quality or insufficient diet. The results of blood tests demonstrate that the animals had normal hepatic function, and that the presented model is good to evaluate the hypothesis that HP could regulate the growth of animals.

In summary, under the conditions of our study and after the analysis of data by the mathematics instruments chosen, it is possible to conclude that HP acquired in early stages of animals' lives does not induce the growth deficit. The growth retardation observed in children with HP can not be experimentally reproduced by inducing HP in young rats. The suggestion that the HP could limit the secretion of a hepatic factor with direct influence in the growth does not find subsidy in this study. 
Miranda LEC, Cenevi va R, Vannucchi H. Efeitos da hipertensão portal sobre o crescimento de ratos jovens. Arq Gastroenterol 2004;41(1):49-53.

RESUMO - Racional - Atraso no crescimento foi observado em crianças com hipertensão portal independentemente da presença de esquistossomose. Sugeriu-se que o desvio de sangue pelas colaterais portossistêmicas justificaria os achados clínicos encontrados. Objetivo-Estudar os efeitos da hipertensão portal no crescimento de ratos jovens. Métodos - O crescimento de 20 ratos di vididos nos grupos hipertensão portal $\mathrm{n}=10,103 \pm 3,7 \mathrm{~g}$ e grupo-controle, $\mathrm{n}=10,102,6 \pm 3,4 \mathrm{~g}$ ) foi avaliado durante 5 semanas. Foram considerados a qualidade da dieta oferecida, a ingestão da dieta, o ritmo de crescimento ganho de peso, a excreção de creatinina urinária, o hematócrito e as provas de função hepática. Ao final do experimento, a pressão portal foi medida por via transesplênica. Resultados/Conclusão - Ratos do grupo hipertensão portal apresentaram atraso de crescimento na 1 semana após a cirurgia, recuperando o seu ritmo de crescimento nas semanas seguintes. Ao final das 5 semanas, não houve diferenças entre os animais. Não houve diferenças com relação às provas bioquímicas e hematológicas, nem com relação ao ganho de massa magra. Esses resultados são evidência contra a hipótese de que hipertensão portal induzida nas fases iniciais da vida desses animais possa provocar atraso de seu crescimento.

DESCRITORES - Hipertensão portal. Transtornos do crescimento. Ratos.

\section{REFERENCES}

1. Abe H, Molitch ME, Van Wyk JJ. Human g rowth and somatomedin C suppress the spontaneous release of $\mathrm{g}$ rowth hor mone in unanesthetized rats. Endocrinology 1983;13:1319-24.

2. Assad SN, Cunningham GR, Samaan NA. Abnor mal growth hor mone dynamics in chronic li ver disease do not depend on severe parenchymal disease. Metabolism 1990;39:349-56.

3. Association of Official Analytical Chemists (AOAC), USA. Official methods of analytical chemists. 12th ed. Washington, 1975. p. 857-957.

4. Atkinson M, Sherlock S. Intrasplenic pressure as index of portal venous pressure Lancet 1954;2:1325-7.

5. Campbell WR, Hanna ML. The deter mination of nitrogen by Kjeldahl methods J Biol Chem 1937;119:1-7.

6. Costa MFFL, Leite MLC, Rocha RS, Magalhães MHA, Katz N. Anthropometric measures in relation to Schistosomiasis mansoni and socioeconomic variables. Int J Epidemiol 1988;17:880-6.

7. Heymsfield SB, Artesga C, Mcmanus C, Smith J, Moffitt S. Measurement of muscle mass in humans: validity of the 24-hour urinary creatinine method. Am J Clin Nutr 1983;3:478-94

8. Holt RI, Jones JS, Baker AJ, Buchanan CR, Mieill JP. The effect of shor t stature, portal hypertension, and cholestasis on growth homone resistance in children with liver disease. J Clin Endocrinol Metabol 1999;84:3277-82.

9. Kato T, Romero R, Koutouby R, Mittal NK, Thompson JF, Schleien CL, Tzakis AG. Portosystemic shunting in children during the era endoscopic therapy: improved postoperative growth parameters. J Pediatr Gastroenterolol Nutr 2000;30:419-25.
10. Latham MC, Stephenson LS, Kurtz KM, Kinoti SN. Metrifonate or praziquantel treatment improves physical fitness and appetite of Kenyan schoolboys with Schistosoma haematobium and hookworm infections. Am J Trop Med Hyg 1990;43:170-9.

11. McGarvey ST, Aligui G, Daniel BI, Peters P, Olveda R, Olds R. Child growth and Schistosomiasis japonica in northeastern Leyte, The Philippines: crosssectional result. Am JTrop Med Hyg 1992;46:571-81.

12. McGarvey ST, Wu G, Zhang S, Wang Y, Peters P, Olds RG, Wiest PM. Child growth, nutritional status, and Schistosomiasis japonica in Jiangxi, people's Republic of China. Am J Trop Med Hyg 1993;48:547-53.

13. Miranda LEC. Avaliação do crescimento de ratos com hipertensão porta [dissertation]. Ribeirão Preto: Faculdade de Medicina de Ribeirão Preto da Universidade de São Paulo; 1997. 97p.

14. Rozga J, Jeppsson B, Hägerstrand I, Bengmark S. Acute portal vein stenosis Acta Chir Scand 1985;151:125-31.

15. Sarin SK, Bansal A, Sasan S, Nigam A. Portal-vein obstruction in children leads to growth retardation. Hepatology 1992;15:229-33.

16. Sarin SK, Agarwal SR. Extrahepatic portal vein obstruction. Semin Liver Dis 2002;22:43-58.

17. Stephenson LS, Latham MC, Kurz MK, Kinoti SN, Oduri LM, Crompton DWT Relationships of Schistosoma haematobium, hookworm and malarial infections and metrifona treatment to growth of kenyan school children. Am J Trop Med Hyg 1985;34:1109-18.

18. Weeb LJ, Sherlock S. The aetiology, presentation and natural history of extrahepatic portal venous obstruction. Q J Med 1979;48:627-39.

Recebido em 22/1/2003. Aprovado em 6/11/2003 